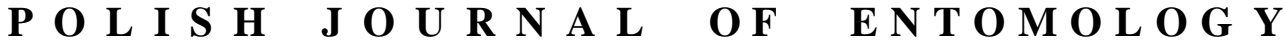

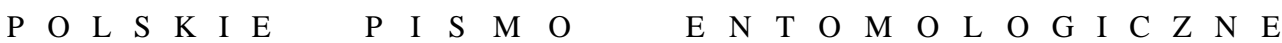

VOL. 86: $165-180$

Lublin

30 June 2017

DOI: $10.1515 /$ pjen-2017-0011

\section{Preliminary observations of necrophagous dipteran activities and a new host record of parasitoids on a high-rise building}

\author{
Chong Chin HeO ${ }^{1,2 *}$, Baha LatiF ${ }^{1}$, Hiromu Kurahashi ${ }^{3}$, Siew Hwa Tan ${ }^{4}$, \\ WAI KIAN CHEW ${ }^{5}$, WASI AHMAD NAZNI ${ }^{5}$, BAHARUDIN OMAR ${ }^{6}$ \\ ${ }^{1}$ Faculty of Medicine, Universiti Teknologi MARA, Sungai Buloh Campus, Jalan Hospital, \\ 47000 Sungai Buloh, Selangor, Malaysia \\ ${ }^{2}$ Institute of Pathology, Laboratory \& Forensic Medicine (I-PPerForM), Universiti \\ Teknologi MARA, Level 4, Academic Building, Faculty of Medicine, 47000 Sungai Buloh, \\ Selangor, Malaysia \\ ${ }^{3}$ International Department of Dipterology, Hikawadai 1-2-21, Higashikurume City, \\ Tokyo 203-0004, Japan \\ ${ }^{4}$ Division of Genetics and Molecular Biology, Institute of Biological Sciences, Faculty \\ of Science, University of Malaya, 50603 Kuala Lumpur, Malaysia \\ ${ }^{5}$ Medical Entomology Unit, Institute for Medical Research, Jalan Pahang, 50588 Kuala \\ Lumpur, Malaysia \\ ${ }^{6}$ Biomedical Science Program, School of Diagnostic \& Applied Health Sciences, Faculty \\ of Health Sciences, Universiti Kebangsaan Malaysia, Jalan Raja Muda Abdul Aziz, \\ 50600 Kuala Lumpur, Malaysia
}

\begin{abstract}
A preliminary study on the ecological activities of necrophagous Diptera on a highrise building in Malaysia was conducted from April to August 2010. Fresh chicken livers (approximately $500 \mathrm{~g}$ ) serving as bait were placed on the rooftop (101.6 m from the ground). Three replicates were carried out, each replicate lasting 30 days with daily observations and fly sampling. Maggots found in the bait were collected at random: some were preserved in $70 \%$ ethanol while the others were reared to the adult stage. Results showed that the flies arrived on the bait between 8 hours and 3 days after placement. The oriental latrine blow fly Chrysomya megacephala (Diptera: Calliphoridae) was the first to reach this altitude, followed by the scuttle fly Megaselia scalaris (Diptera: Phoridae) and the flesh fly Liopygia ruficornis (Diptera: Sarcophagidae). The larvae of Chrysomya megacephala were first recovered from the bait. However, they were succeeded by sarcophagid larvae. The predominant sarcophagid larvae were then raised to the adult stage and the resulting adults were identified as Parasarcophaga dux. The other sarcophagid pupae were either
\end{abstract}

*Corresponding author: chin@salam.uitm.edu.my 
parasitized by hymenopteran parasitoids or dead. We recorded two species of parasitoids emerging from Liopygia ruficornis pupae: Exoristobia philippinensis (Hymenoptera: Encyrtidae) and Dirhinus himalayanus (Hymenoptera: Chalcididae). Liopygia ruficornis is recorded as a new host for these parasitoids for the first time.

KEY WORDS: carrion flies, high-rise building, Liopygia ruficornis, Exoristobia philippinensis, Dirhinus himalayanus, new host record, Malaysia.

\section{INTRODUCTION}

Oviposition by flies is elicited mainly by the presence of ammonia-rich compounds, but also by moisture, pheromones and tactile stimuli (ASHWORTH \& WALL 1994). Oviposition on an animal usually occurs immediately after its death (ANDERSON \& VANLAERHOVEN 1996). Blow flies can be attracted to carrion over great distances by specific odours (BRAACK 1981). The timing of oviposition can be affected by several factors such as accessibility to the cadaver (ANDERSON 2001, POHJOISMÄKI et al. 2010), atmospheric temperature (CRAGG 1956, PAYNE 1965), precipitation (MAHAT et al. 2009), humidity (BROWNE 1958), insecticides (MAHAT et al. 2009, RUMIZA et al. 2010), seasons (INTRONA 1991), presence of sunlight (MACGREGOR 1999a, 1999b), habitat characteristics (HOBISCHAK 1997, SILAHUDDIN et al. 2015), burial (RODRIGUEZ \& BASS 1985, VANLAERHOVEN \& ANDERSON 1999), presence of semiochemicals (WALL \& FISHER 2001, LEBLANC \& LOGAN 2010), pheromones (ELNAIEM \& WARD 1990, 1991), and can be facilitated through interkingdom signalling between microbes and blow flies (MA et al. 2012, DAVIS et al. 2013).

Several decomposition studies using animal carcasses in Malaysia have also indicated that oviposition was initiated immediately after death (OMAR et al. 1994, HEO et al. 2007) and that the insect succession patterns were basically similar in those cases (OMAR et al. 1992, 1994). The pioneering colonizers on cadavers are calliphorids such as Chrysomya megacephala (FABRICIUS, 1794) and Chrysomya rufifacies (MACQUART, 1842) and are succeeded by flesh flies (Sarcophagidae) and muscid flies (Muscidae) (LEE \& MARZUKI 1993, OMAR et al. 1994, HEO et al. 2007, 2008). LEE et al. (2004) and AHMAD et al. (2007) concluded that the predominant forensically important blow fly species were those from the genus Chrysomya RoBINEAU-DESVOIDY, 1830.

Synthesiomyia nudiseta VAN DER WULP, 1883 (Diptera: Muscidae) was reported to colonize a dead body found on a thirteen-storey building in Malaysia (SYAMSA et al. 2012). However, little information is known regarding the arrival time and the community composition of necrophagous Diptera on buildings more than 20 floors high. The present paper provides some preliminary observations on ecological activities such as succession, 
oviposition and parasitism of necrophagous insects on a high-rise building. We also report a new host record for two parasitoid species in Malaysia.

\section{MATERIAL AND METHODS}

Fresh chicken liver (weight approximately $500 \mathrm{~g}$ ) was used as bait and placed on the rooftop of a tower located at the Universiti Teknologi MARA (UiTM) $\left(3^{\circ} 04^{\prime} 21^{\prime \prime} \mathrm{N}\right.$ $101^{\circ} 29^{\prime} 77^{\prime \prime} \mathrm{E}, 24 \mathrm{~m}$ amsl), which is at a height of $101.6 \mathrm{~m}$ above the ground (on the $21^{\text {st }}$ floor). A total of three replicates were carried out in sequence between April and August 2010. The first day of the experiment was designated as Day 1. Each replicate lasted for 30 days and observations were recorded daily during two visits per day to the rooftop: in the morning ( 10:00 hrs) and in the afternoon ( 16:00 hrs). Permission from the building authority was obtained to utilize the study site. The rooftop is open, uncovered, with a water pump and a water storage tank located in the centre.

The bait was placed below the water storage tank, which acted as a shelter to prevent desiccation due to direct sunlight. Water was added ad libitum to maintain bait moisture. Meteorological data such as daily temperatures, humidity and precipitation throughout the study period $\left(27^{\text {th }}\right.$ April $-4^{\text {th }}$ August 2010) were retrieved from the nearest weather station (Kuala Lumpur International Airport; $2^{\circ} 44^{\prime} 51^{\prime \prime N} ; 101^{\circ} 42^{\prime} 49^{\prime \prime} \mathrm{E}$ ). Adult flies attracted to the bait were collected by sweeping and transferred to a glass jar containing chloroform. All adult specimens were pinned, labelled, dried and kept in insect storage boxes. The adult specimens were identified to the lowest possible taxonomic rank using the keys by Kurahashi et al. (1997), GreEnBERG \& KUnich (2002) and Triplehorn \& JOHNSON (2005).

Maggots found on the bait were collected randomly: some were preserved in $70 \%$ ethanol, while the others were allowed to complete their life cycle. The preserved larvae were mounted on slides following the procedures suggested by LEE et al. (2004). The larval morphology was studied and identified using the keys by ISHIJIMA (1967), GREENBERG $\&$ KUNICH (2002) and SZPILA (2010). Pupae collected from the site were placed in a bijou bottle (diameter $25 \mathrm{~mm}$; height $85 \mathrm{~mm}$ ) with a screw cap. Emergent adult insects were pinned, labelled and identified. A digital stereomicroscope (Olympus SZX7, Japan) and a compound microscope (Olympus BX5, Japan) were employed for imaging and measuring purposes.

The dead and parasitized pupae were identified using a molecular technique. The DNA of each pupa was extracted using the QIAamp ${ }^{\circledR}$ DNA Mini Tissue Kit (Qiagen, Germany) following the manufacturer's protocols. PCR amplification of cytochrome oxidase subunit I and II (COI+II) prior to DNA sequencing was carried out according to TAN et al. (2010). 
The DNA sequences obtained were then aligned using Molecular Evolutionary Genetics Analysis (MEGA) version 4.0 (TAMURA et al. 2007) and compared with the local fly DNA databank.

\section{RESULTS}

\section{Climatological data}

The average maximum and minimum temperatures recorded by the nearest weather station were $33.93 \pm 1.33{ }^{\circ} \mathrm{C}$ and $24.61 \pm 0.90{ }^{\circ} \mathrm{C}$, respectively. The mean temperature was $29.28 \pm 0.90{ }^{\circ} \mathrm{C}$ while the mean relative humidity was $83.85 \pm 3.12 \%$; the total precipitation during the study period was $776.25 \mathrm{~mm}$.

\section{Dipteran succession and oviposition/larviposition activities}

The time of fly arrival, varying between replicates, ranged from 8 hours to 3 days. The oriental latrine blow fly Chrysomya megacephala was the first taxon to reach the study site; it was followed by the scuttle fly Megaselia scalaris (LOEW, 1866) (Diptera: Phoridae) and the flesh fly Liopygia ruficornis (FABRICIUS, 1794) (Diptera: Sarcophagidae). Other than Diptera, ants (Hymenoptera: Formicidae) were de facto the first insects to arrive on the bait. However, the population of ants was not abundant and had no obvious deterrent effect on fly oviposition/larviposition. It was observed that the adult flies were most active during the daytime and that their activities ceased in the late evening ( 19:00 hrs). 30 adult flies that had been attracted to the bait from April-May were collected and identified. Adults of Chrysomya megacephala were the earliest dipterans to arrive and were seen around the bait for a week. Adults of both Liopygia ruficornis and Megasielia scalaris arrived on the bait on the second day. These species were observed to be present on the bait for more than three weeks. Predatory insects such as spiders and wasps Vespa sp. (Hymenoptera: Vespidae) were also observed in the mid or later stage of liver decomposition (from Day 9 onwards).

Within the first 8 hours of bait exposure, a batch of yellowish eggs was deposited by Chrysomya megacephala. The first instars hatched from the eggs on the second day and then developed into $2^{\text {nd }}$ instars on the third day. On the fourth and subsequent days, $3^{\text {rd }}$ instars were present. Larval stages of three fly species, namely $C$. megacephala, Liopygia ruficornis and Parasarcophaga dux (THOMSON, 1869) (Diptera: Sarcophagidae), were recorded on the bait from the second day onwards. In less than a week, Chrysomya megacephala larvae were replaced by sarcophagid larvae, which eventually dominated the bait. The underlying reason for this larval succession was not clear, i.e. it could not be determined whether C. megacephala larvae were predated by sarcophagids. Although some 
post-feeding sarcophagid larvae migrated from the bait to a drier place for pupation, many others remained on the chicken livers. The first pupa was found on the seventh day. Throughout the decomposition process, the adult phorid flies were seen scuttling around the bait, but no oviposition was initiated. We failed to collect adult Parasarcophaga dux from the field, although its larvae and pupae were recovered from the baits. All adult sarcophagids collected were identified morphologically as Liopygia ruficornis.

\section{Parasitism}

Molecular analysis of all parasitized pupae revealed the species of Liopygia ruficornis. In general, the survival rate of Sarcophagidae in this replicate was $25 \%$ (all emerged as Parasarcophaga dux), while the percentage of parasitism was 58\%. In contrast, there was $100 \%$ mortality in Liopygia ruficornis pupae. The complete life cycle of Parasarcophaga $d u x$ from eggs to adults was 15 to 22 days $\left(\mathrm{n}=3\right.$, mean temperature $\left.29.95 \pm 0.75^{\circ} \mathrm{C}\right)$. The developmental duration of the larval stage was 4 to 9 days. The first pupae formed on Day 7 and the pupal stage lasted for $11-13$ days (Table 1 ).

Table 1. Developmental duration of Parasarcophaga dux (Diptera: Sarcophagidae) $(\mathrm{n}=3$; mean temperature $29.95 \pm 0.75^{\circ} \mathrm{C}$ ).

\begin{tabular}{|l|c|c|}
\hline \multicolumn{1}{|c|}{ Developmental stages } & Day & Cumulative day \\
\hline $1^{\text {st }}$ instar larva (through larviposition) & 1 & 1 \\
\hline $2^{\text {nd }}$ instar larva & 1 & 2 \\
\hline $3^{\text {rd }}$ instar larva (including post-feeding stage) & $2-7$ & $4-9$ \\
\hline Pupa & $11-13$ & $15-22$ \\
\hline Adult & Emerged between Day 15 and 22 \\
\hline
\end{tabular}

We reported two species of parasitoids emerged from Liopygia ruficornis pupae, namely Exoristobia philippinensis ASHMEAD, 1904 (Hymenoptera: Encyrtidae) (Fig. 1) and Dirhinus himalayanus WeSTWOOD, 1836 (Hymenoptera: Chalcididae) (Fig. 2).

The total "pupation period" for fly pupae $(\mathrm{n}=2)$ parasitized by Exoristobia philippinensis ranged from 20 to 23 days at a mean temperature $29.83 \pm 0.84{ }^{\circ} \mathrm{C}$, which was prolonged for another $8-12$ days (in comparison with the normal pupation period for Liopygia ruficornis, reported as $11.7 \pm 0.14$ days at $27 \pm 4{ }^{\circ} \mathrm{C}$ (SUKHAPANTH et al. 1988). The parasitoids emerged from the fly pupae through several self-chewed circular holes on the puparium. Exoristobia philippinensis emerged in a swarm of $20-50$ individuals from a single pupa. Table 2 summarizes the developmental period for E. philippinensis. 


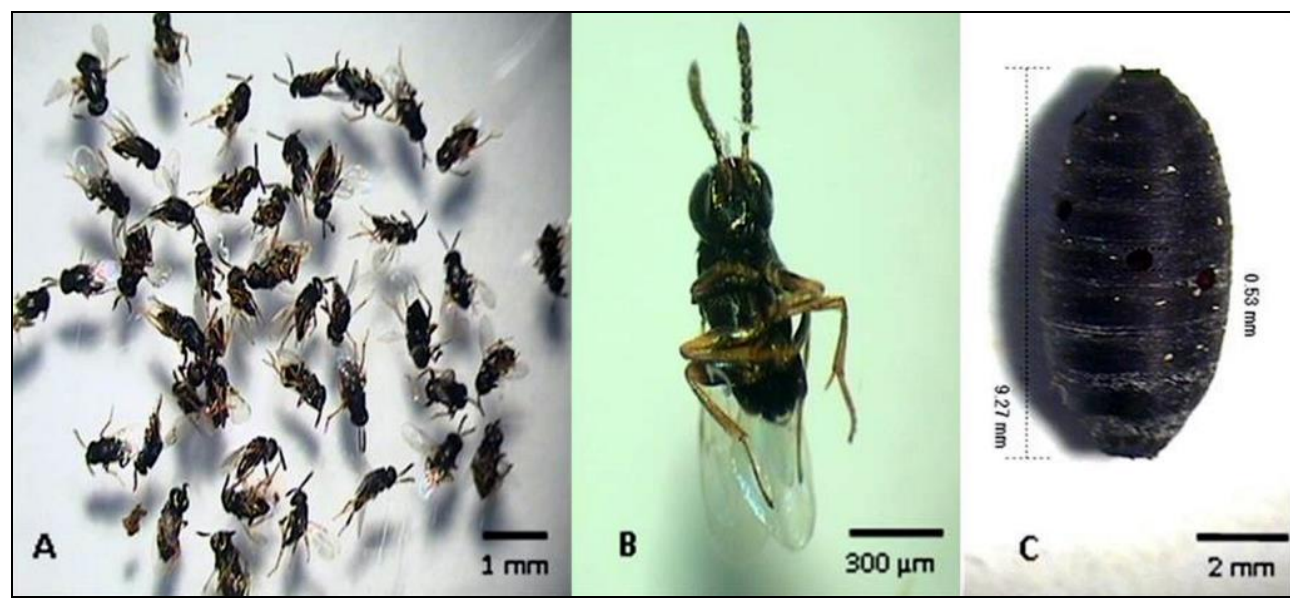

Fig. 1. A. Exoristobia philippinensis (Hymenoptera: Encyrtidae) emerged in a group from a Liopygia ruficornis pupa. B. Close-up view of Exoristobia philippinensis. C. Dead Liopygia ruficornis pupa parasitized by Exoristobia philippinensis with four tiny circular holes (average hole diameter $0.53 \mathrm{~mm}$ ).

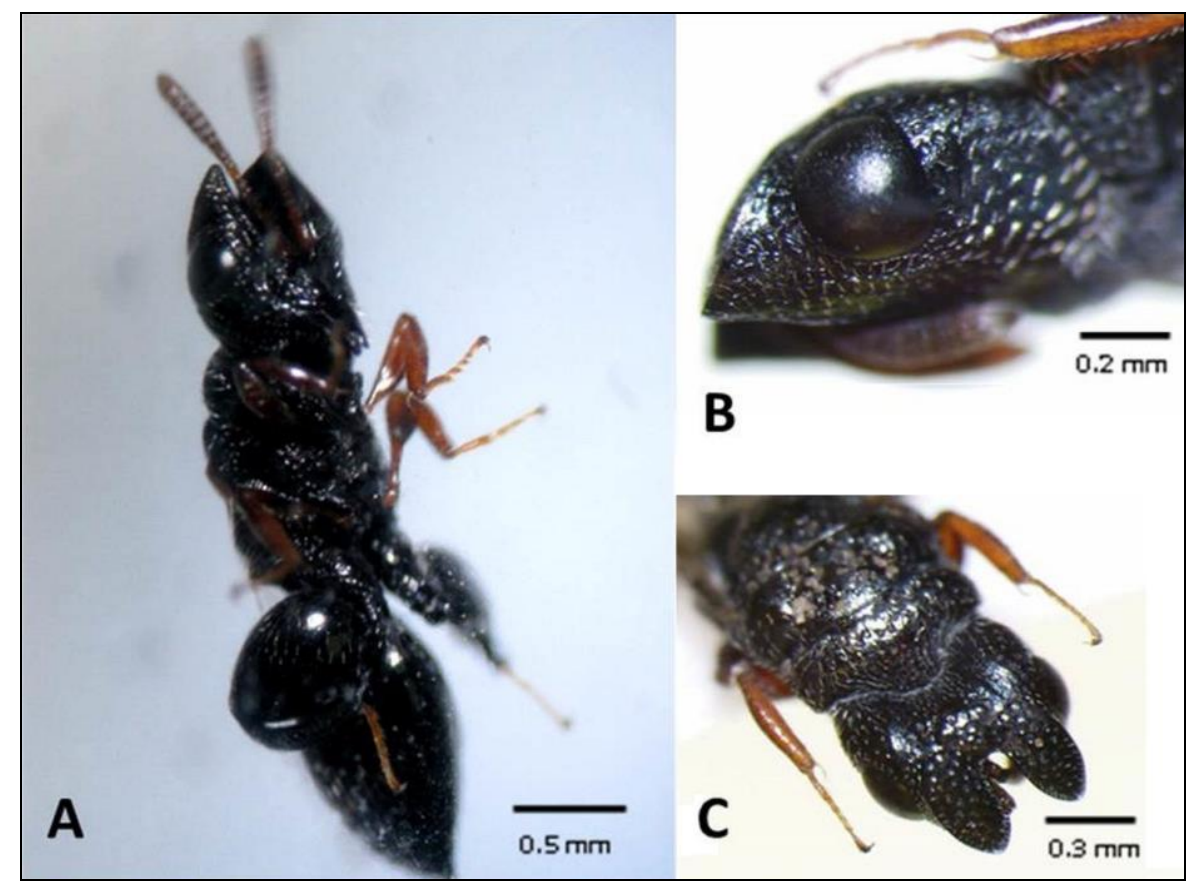

Fig. 2. A. Newly emerged Dirhinus himalayanus (Hymenoptera: Chalcididae) from a Liopygia ruficornis pupa. Note the swollen hind femur (arrow). B. Lateral view of head. C. Dorsal view of head. 
Table 2. Developmental duration for Exoristobia philippinensis and total number of parasitoids emerged from Liopygia ruficornis pupae $(\mathrm{n}=2$; mean temperature $29.83 \pm 0.84$ ${ }^{\circ} \mathrm{C}$ ). Table headers: ID - pupa ID, DL - date of larviposition, DP - date of pupariation, $\mathrm{DE}$ - date of parasitoid emergence, PS - pupal stage (day), $\mathrm{N}$ - number of parasitoids emerged, PP - "prolonged pupal stage" (day) as compared to unparasitized L. ruficornis pupa.

\begin{tabular}{|c|c|c|c|c|c|c|}
\hline ID & DL & DP & DE & PS & $\mathbf{N}$ & PP* \\
\hline 1 & $28^{\text {th }}$ April & $4^{\text {th }}$ May & $27^{\text {th }}$ May & 23 & 20 & \multirow{2}{*}{$8-12$} \\
\hline 2 & $28^{\text {th }}$ April & $7^{\text {th }}$ May & $27^{\text {th }}$ May & 20 & 47 & \\
\hline 3 & Unknown & Unknown & $27^{\text {th }}$ May & Indeterminable & 50 & \multirow{2}{*}{ Indeterminable } \\
\hline 4 & Unknown & Unknown & $27^{\text {th }}$ May & Indeterminable & 24 & \\
\hline
\end{tabular}

* the normal pupal stage in Liopygia ruficornis lasts $11-12$ days at $27 \pm 4{ }^{\circ} \mathrm{C}$ (SUKHAPANTH et al. 1988)

An adult of Dirhinus himalayanus was first sighted as it landed on a pupa on Day 15. On the next day, we collected four sarcophagid pupae from the site; three of them had been parasitized, the parasitoid (D. himalayanus) emerging 30 - 32 days later. The unparasitized pupa developed into an adult Parasarcophaga dux. On Day 17, another five pupae were collected. Three of them were parasitized by Dirhinus himalayanus and one was parasitized by Exoristobia philippinensis; no parasitoid or adult fly emerged from the last pupa, so it was presumed dead. The percentage of pupal parasitism was $67 \%$ by Dirhinus himalayanus and $11 \%$ by Exoristobia philippinensis. Only one adult Parasarcophaga dux emerged from the nine pupae collected; the survival rate was thus very low $(11 \%)$. The developmental period for Dirhinus himalayanus $\left(\mathrm{n}=6\right.$; mean temperature $\left.26.32 \pm 1.99{ }^{\circ} \mathrm{C}\right)$ is summarized in Table 3. Survival rate, percentage of parasitism and mortality rate between the replicates are compared in Table 4. All the specimens from the parasitized pupae belonged to Liopygia ruficornis (species identity confirmed by molecular technique), and the emerged adults were identified morphologically as Parasarcophaga dux.

Table 3. Developmental duration for Dirhinus himalayanus in Liopygia ruficornis pupae $\left(\mathrm{n}=6\right.$; mean temperature $\left.26.32 \pm 1.99^{\circ} \mathrm{C}\right)$. Table headers as in the Table 2 .

\begin{tabular}{|c|c|c|c|c|c|c|}
\hline ID & DL & DP & DE & PS & N & \multirow{2}{*}{ PP* } \\
\hline $\mathbf{5}$ & $20^{\text {th }}$ July & $3^{\text {rd }}$ August & $2^{\text {nd }}$ September & 30 & 1 & \\
\hline $\mathbf{6}$ & $20^{\text {th }}$ July & $3^{\text {rd }}$ August & $3^{\text {rd }}$ September & 31 & 1 \\
\cline { 1 - 5 } $\mathbf{7}$ & $20^{\text {th }}$ July & $3^{\text {rd }}$ August & $4^{\text {th }}$ September & 32 & 1 & \multirow{2}{*}{$18-23$} \\
\hline $\mathbf{8}$ & $20^{\text {th }}$ July & $4^{\text {th }}$ August & $5^{\text {th }}$ September & 32 & 1 & \\
\hline $\mathbf{9}$ & $20^{\text {th }}$ July & $4^{\text {th }}$ August & $5^{\text {th }}$ September & 32 & 1 & \\
\hline $\mathbf{1 0}$ & $20^{\text {th }}$ July & $4^{\text {th }}$ August & $7^{\text {th }}$ September & 34 & 1 & \\
\hline
\end{tabular}

* the normal pupation period in Liopygia ruficornis lasts $11-12$ days at $27 \pm 4{ }^{\circ} \mathrm{C}$ (SUKHAPANTH et al. 1988) 
Table 4. Percentage of survival, parasitism and mortality of sarcophagid pupae during the study period.

\begin{tabular}{|l|c|c|}
\hline Mercentage (\%) & April - May & July - August \\
\hline Survival & $25^{\mathrm{a}}$ & $11^{\mathrm{b}}$ \\
\hline Parasitism & $58^{\mathrm{c}}$ & $78^{\mathrm{d}}$ \\
\hline Mortality & 17 & 11 \\
\hline Total & $100(\mathrm{n}=12$ pupae $)$ & $100(\mathrm{n}=9$ pupae $)$ \\
\hline
\end{tabular}

a. All emerged adults were Parasarcophaga dux $(\mathrm{n}=3)$.

b. The emerged adult was $P . d u x(\mathrm{n}=1)$.

c. $58 \%$ of sarcophagid pupae were parasitized by Exoristobia philippinensis. All parasitized pupae were Liopygia ruficornis $(\mathrm{n}=7)$.

d. $67 \%$ of sarcophagid pupae were parasitized by Dirhinus himalayanus and $11 \%$ by Exoristobia philippinensis. (Total percentage of parasitism $=78 \%$ ). All parasitized pupae were Liopygia ruficornis $(\mathrm{n}=7)$.

\section{DISCUSSION}

Temperature, rainfall and humidity are the main factors influencing dipteran oviposition, especially in an open area. MAHAT et al. (2009) concluded that rain, depending on its intensity, delayed oviposition by $1-2$ days and prolonged the pupation period to $1-3$ days. However, in the present study, no rain was recorded on the first day of the experiment.

The life cycle of Parasarcophaga dux, based on the emerged adults available, ranged between 15 - 22 days, with a larval stage of $4-9$ days and a pupal stage lasting $11-13$ days. In Guam, BOHART \& GRESSITT (1951) reported that larval development in P. dux was seven days at a temperature of $29.5^{\circ} \mathrm{C}$. ALWAR \& SESHIAH (1958) carried out a study in India at temperatures of $23-34{ }^{\circ} \mathrm{C}$ and found that the larval stage lasted 4-8 days. This finding is very similar to our result. In South Africa, the larval stage was longer at $25^{\circ} \mathrm{C}$, i.e. 8.2 - 10.2 days (ASPOAS 1991). In Malaysia, THEVAN et al. (2013) studied the larval growth of $P$. dux at temperatures fluctuating around $28.9 \pm 1.2{ }^{\circ} \mathrm{C}$ and a relative humidity of $64 \pm 10 \%$; they found that the larval and pupal stages of $P$. dux lasted for 5.5 days and 3.8 days, respectively. A total of 12.8 days elapsed from the first instar to adult emergence. In Thailand, SUKONTASON et al. (2010) reported that there were differences in developmental duration according to season. They found that prepupae began to form 72 hours, $84 \pm 12$ hours and 96 hours after the first instar's appearance in summer, the rainy season, and winter, respectively. In Saudi Arabia, development of $P$. $d u x$ varied according to temperature and was faster at higher temperatures: developmental duration from first instar to adult emergence required 51.8, 33.0, 25.0, 16.4, and 15.1 days when reared at 16 , 20, 24, 28, 32 and $36{ }^{\circ} \mathrm{C}$, respectively (AL-Misned 2004). Developmental studies have shown variability in the life cycle of $P$. $d u x$ according to seasons, temperatures and 
geographical locations across the globe. This phenomenon could be due to differences in genotypes as well as phenotypic plasticity (TARONE \& FORAN 2006, HWANG \& TURNER 2009).

Various parasitoid species from different dipteran hosts have been reported in Malaysia by OMAR et al. (1988, 1991, 2008), Sulaiman et al. (1990, 1991, 1993) and HeO et al. (2009). BOUCHEK \& NARENDRAN (1981) recorded Dirhinus himalayanus from Sarcophaga sp. while SUlaIMAN et al. (1990) found Dirhinus himalayanus to parasitize only pupae of Musca domestica LINNAEUS, 1758 collected in a poultry farm in Malaysia. KADARSAN \& JEFFERY (1981) found that a colony of Sarcophaga sp. in the laboratory was parasitized by Exoristobia philippinensis. OMAR et al. (2008) and HeO et al. (2009) documented the natural hosts of E. philippinensis as Musca domestica and Chrysomya rufifacies, respectively.

In this study, we determined that Liopygia ruficornis is a natural host of Exoristobia philippinensis and Dirhinus himalayanus. Moreover, the ability of these parasitoids to search for and locate host pupae in a high-rise building is remarkable. We noticed that both species of parasitoids parasitized fly pupae at different intervals, and we hypothesized that this could be a behaviour to avoid interspecific competition. For instance, Exoristobia philippinensis arrived earlier than Dirhinus himalayanus: whether there is a successional wave of parasitoids cannot be ruled out. It is not clear why D. himalayanus was absent during April-May but present in the later months (July - August): perhaps this was due to differences in the bionomics or temporal dynamics of that particular species. The high percentage of pupal parasitism by $D$. himalayanus implies that it might be the dominant species or perhaps a superior competitor to Exoristobia philippinensis. Other than interspecific competition, facultative hyperparasitism or intraguild predation could occur (FISCHER 1991, CUSUMANO et al. 2013). According to this hypothesis, Dirhinus himalayanus might inject its eggs into fly pupae that have already been parasitized by Exoristobia philippinensis. However, further investigations on multiple parasitism or hyperparasitism should be carried out on these parasitoids. GADEN et al. (2006) studied the attack rate of parasitoids and found that Dirhinus himalayanus had the highest rates of host attack and progeny production from Sarcophaga bullata (PARKER, 1916) (Diptera: Sarcophagidae) and Hydrotaea aenescens (WIEDEMANn, 1830) (Diptera: Muscidae), followed by Stomoxys calcitrans (LINNAEUs, 1758) and Musca domestica. Besides, the differences in life histories demonstrated by Dirhinus himalayanus and philippinensis may play a role in their successful parasitism. In this case, Dirhinus himalayanus seems to possess a K-selection strategy, as it produces only one offspring per individual host, and has a larger body size and a longer life span. In contrast, Exoristobia philippinensis exhibited properties of an r-strategist, such as a shorter developmental time, a smaller body size, the production of multiple offspring from one individual host, as well as the lower 
probability of surviving to adulthood (MACARTHUR \& WILSON 1967).

All emerged adults from pupae were identified as Parasarcophaga dux but none of the Liopygia ruficornis pupae survived parasitoid attack. There are two possible explanations for this: 1) preference of parasitoids, 2) temporal mismatch between the formation of Parasarcophaga dux pupae and the arrival of the parasitoid. Parasitoids may have preference over another host if given a choice, where this choice might include types of habitats, as well as the volatile chemicals, odours, age, size, shape and texture of the hosts (VINSON 1976). Temporal mismatch is defined here as the difference between host pupation time and the arrival time of parasitoids. As such, P. dux outcompeted Liopygia ruficornis through apparent competition by manipulating the pupation time. However, this hypothesis needs to be examined empirically in order to understand the host-parasitoid interactions.

The parasitism of fly pupae can be vitally important, especially in the determination of the minimum postmortem Interval (mPMI), as highlighted by workers from Australia (Voss et al. 2009, 2010). Both species are likely to serve as indicators of mPMI owing to their high percentage of parasitism in this study. In our study, the "prolonged pupation period" was due to parasitism. In fact, the "prolonged pupation period" was due to the parasitoid larvae feeding on the developing pharate within the puparium and eventually killing the host (GRASSBERGER \& FRANK 2003). Therefore, we recommend forensic entomologists to retain fly pupae until eclosion for a longer period in order to allow for the possible emergence of parasitoids, which might be useful for the determination of mPMI by working backwards based on the developmental time of the dipteran host (from eggs to pupal stage) and the developmental periods of parasitoids (from egg insertion to parasitoid emergence). In the case of Exoristobia philippinensis, the first parasitized sarcophagid pupa could have occurred on Day 6 or 7 after bait exposure and the pupation period could last for 23 days, whereas Dirhinus himalayanus parasitized the first pupa on Day 12 or 13 and remained in the pupa for another 34 days. In general, we noted that $D$. himalayanus had a longer development time than Exoristobia philippinensis. This result was almost identical to that of SRINIVASAN \& AMALRAJ (2003), who found a mean generation time for Dirhinus himalayanus of 36 days. GRASSBERGER \& FRANK (2003) studied the relationship between temperature and the development time of a parasitoid, Nasonia vitripennis (WALKER, 1836), on the pupae of Protophormia terraenovae RoBINEAU-DESVOIDY, 1830 (Diptera: Calliphoridae). They found that the development time was inversely correlated with temperature in this species and suggested the use of parasitoids as a reliable mPMI indicator. In nature, fly pupae are mostly found buried under the soil (DENLINGER 1972, OMAR et al. 1994, HEO et al. 2008), which is what may protect them from becoming parasitized. GADEN (2002) did a study on the efficacy of parasitoid attack on host pupae in different types of habitats and at different depths. He found that Dirhinus himalayanus confined itself to the soil surface when searching for a suitable fly host in manure, and the 
number of pupae killed fell with increasing soil depth. In this study, the floor on the rooftop is made of concrete; the larvae thus have to pupate on this surface, which exposes them to the external environment. Consequently, forensic entomologists should be alert to the fact that exposed fly pupae may be parasitized and should monitor the emergence of parasitoids.

In this study, we highlight the ecological and biological activities (succession and oviposition/larviposition) of necrophagous dipterans on a high-rise building, the general developmental duration of Parasarcophaga dux, a new host record of a parasitoid (i.e., Liopygia ruficornis) and parasitoid developmental duration in the hosts. Entomological studies should be carried out in urban environments as rapid urbanization has driven changes in insect ecology, and consequently in the application of insect sciences.

\section{ACKNOWLEDGEMENTS}

We would like to thank the Faculty of Medicine, Universiti Teknologi MARA, for the laboratory facilities provided to us during this study. Also, we thank Dr John S. NOYES (Natural History Museum, UK) and the late Prof. Dr T.C. NARENDRAN (Calicut University, India) for their kind assistance in confirming the species of parasitoids. We also express our gratitude to Mr Haji SUlAiman ABDULlaH for his technical support throughout the study. The constructive comments from the reviewers of this manuscript are greatly appreciated.

\section{REFERENCES}

Ahmad F.M.S., Mohamad A.M., Afandy N., JefFery J., Omar B. 2007. Review of forensic cases from Kuala Lumpur Hospital and Hospital Universiti Kebangsaan Malaysia in year 2002. Journal of Tropical Medicine and Parasitology 30(2): 51-54.

AL-MisnED F.A. 2004. Effect of temperature on development and mortality of immature Sarcophaga (Liosarcophaga) dux THомson (Diptera: Sarcophagidae). Journal of King Saud University, Agricultural Sciences 16: 53-60.

Alwar V.S., Seshiah S. 1958. Studies on the life history and bionomics of Sarcophaga dux THOMPSON, 1868. Indian Veterinary Journal 35(11): 559-565.

Amendt J., Campobasso C.P., Gaudry E., Reiter C., LeBlanc H.N., Hall M.J.R. 2007. Best practice in forensic entomology - standard and guidelines. International Journal of Legal Medicine 121(2): 90-104.

ANDERSON G.S. 2001. Insect succession on carrion and its relationship to determining time of death. In: J.H. BYRD, J.L. CASTNER (Eds). Forensic Entomology. The utility of arthropods in legal investigations. CRC Press, Boca Raton, 143-175. 
ANDERSON G.S., CERVEnKa V.J. 2002. Insects associated with the body: their use and analyses. In: W.D. Haglund, M.H. Sorg (Eds). Advances in forensic taphonomy - method, theory and archaeological perspectives. CRC Press, Boca Raton, 173-200.

ANDERSON G.S., VANLAERHOVEN S.L. 1996 Initial studies on insect succession on carrion in Southwest British Columbia. Journal of Forensic Science 41(4): 617-625.

ASHWORTH J.R., WaLl R. 1994. Responses of the sheep blowflies Lucilia sericata and L. cuprina to odour and the development of semiochemical baits. Medical and Veterinary Entomology 8(4): 303-309.

ASPOAS B.R. 1991. Comparative micromorphology of third instar larvae and the breeding biology of some Afrotropical Sarcophaga (Diptera: Sarcophagidae). Medical and Veterinary Entomology 5(4): 437-445.

Bohart G.E., Gressitt J.L. 1951. Filth-inhabiting flies of Guam. Bernice P. Bishop Museum Bulletin 204: 1-151.

BouĉEK Z., NARENDRAN T.C. 1981. Indian chalcid wasps (Hymenoptera) of the genus Dhirnus parasitic on synanthropic and other Diptera. Systematic Entomology 6(3): 229-251.

BRAACK L.E.O. 1981. Visitation patterns of principal species of the insect complex at carcasses in the Kruger National Park. Koedoe 24(1): 33-49.

BROwnE B.L. 1958. The choice of communal oviposition sites by the Australian sheep blowfly Lucilia cuprina. Australian Journal of Zoology 6(3): 241-247.

BYRD J.H., CASTNER J.L. 2001. Forensic Entomology. The utility of arthropods in legal investigations. CRC Press, Boca Raton.

Campobasso C.P., Di Vella G., Introna F. 2001. Factors affecting decomposition and Diptera colonization. Forensic Science International 120(1): 18-27.

Coe J.I., Curran W.J. 1980. Definition and time of death. In: W.J. Curren, A.L. McGarry, C.S. PETTY (Eds). Modern Legal Psychiatric Forensic Science. Davis Co, Philadelphia, 140-169.

CRAGG J.B. 1956. The olfactory behavior of Lucilia species (Diptera) under natural condition. Annals of Applied Biology 44(3): 467-477.

Cusumano A., Peri E., Amodeo V., McNeil J.N., Colazza S. 2013. Intraguild interactions between egg parasitoids: window of opportunity and fitness costs for a facultative hyperparasitoid. PLoS One 8(5): e64768.

DAvis T.S., CRIPPEn T.L., Hofstetter R. W., TOMBerLin J. K. 2013. Microbial volatile emissions as insect semiochemicals. Journal of Chemical Ecology 39(7): 840-859.

DENLINGER D.L. 1972. Induction and termination of pupal diapause in Sarcophaga (Diptera: Sarcophagidae). The Biological Bulletin 142(1): 11-24.

Disney R.H., MANLOVE J.D. 2005. First occurrences of the phorid, Megaselia abdita, in forensic cases in Britain. Medical and Veterinary Entomology 19(4): 489-491.

ELNAIEM D.A., WARD R.D. 1990. An oviposition pheromone on the eggs of sandflies (Diptera: Psychodidae). Transactions of the Royal Society of Tropical Medicine and Hygiene 84(3): 456-457.

ELNAIEM D.A., WARD R.D. 1991. Response of the sandfly Lutzomyia longipalpis to an oviposition pheromone associated with conspecific eggs. Medical and Veterinary Entomology 5(1): 87-91. 
FISCHER H.U. 1991. Hyperparasitism in two newly introduced parasitoids, Epidinocarsis lopezi and Gyranusoidea tebygi (Hymenoptera: Encyrtidae) after their establishment in Togo. Bulletin of Entomological Research 81(2): 127-132.

GADEN C.J. 2002. Effect of habitat depth on host location by five species of parasitoids (Hymenoptera: Pteromalidae, Chalcididae) of house flies (Diptera: Muscidae) in three types of substrates. Environmental Entomology 31(2): 411-417.

GADEN C.J., Moon R.D., Butler J.F. 2006. Host ranges of six solitary filth fly parasitoids (Hymenoptera: Pteromalidae, Chalcididae) from Florida, Eurasia, Morocco and Brazil. Environmental Entomology 35(2): 405-412.

GRASSBERgER M., Frank C. 2003. Temperature-related development of the parasitoid wasp Nasonia vitripennis as forensic indicator. Medical and Veterinary Entomology 17(3): 257-262.

GREENBERG B., Kunich J.C. 2002. Entomology and the law. Flies as forensic indicators. Cambridge University Press, UK.

Henssge C., Madea B., Knight B., Nokes L., Krompecher T. 1995. The estimation of the time since death in the early postmortem interval. Edward Arnold, London.

Heo C.C., Mohamed A.M., Ahmad F.M.S., Jeffery J., Kurahashi H., Omar B. 2008. Study of insect succession and rate of decomposition on a partially burned pig carcass in an oil palm plantation in Malaysia. Tropical Biomedicine 25(3): 202-208.

Heo C.C., Mohamed A.M., Ahmad F.M.S., JefFery J., Omar B. 2007. A preliminary study of insects succession of a pig carcass in a palm oil plantation in Malaysia. Tropical Biomedicine 24(2): 23-27.

Heo C.C., Nazni W.A., Lee H.L., JefFery J., Chen C.D., Lau K.W., Omar B., Sofian-Azirun M. 2009. Predation on pupa of Chrysomya rufifacies (MARQUART) (Diptera: Calliphoridae) by parasitoid, Exoristobia philippinensis ASHMEAD (Hymenoptera: Encyrtidae) and Ophyra spinigera larva (Diptera: Muscidae). Tropical Biomedicine 26(3): 369-372.

HOBISCHAK N.R. 1997. Freshwater invertebrate succession and decompositional studies on carrion in British Columbia. M.P.M. thesis. Department of Biological Sciences. Burnaby, British Columbia. Simon Fraser University, Canada.

Hwang C. C., TuRner B. D. 2009. Small-scaled geographical variation in life-history traits of the blowfly Calliphora vicina between rural and urban populations. Entomologia Experimentalis et Applicata 132(3): 218-224.

INTRONA F.J., SumAn T.W., SMiALEK J.E. 1991. Sarcosaprophagous fly activity in Maryland. Journal of Forensic Science 36(1): 238-243.

IsHiJima H. 1967. Revision of the third stage larvae of synanthropic flies of Japan (Diptera: Anthomyiidae, Muscidae, Calliphoridae and Sarcophagidae). Japanese Journal of Sanitary Zoology 18(2-3): 47-100.

KADARSAN S., JEFFERY J. 1981. Exoristobia philippinensis, a common parasitoid of synanthropic flies (Hymenoptera, Encyrtidae). Southeast Asian Journal of Tropical Medicine and Public Health 12: 615-616.

Kurahashi H., Benjaphong N., OMar B. 1997. Blow flies (Insecta: Diptera: Calliphoridae) of Malaysia and Singapore. Raffles Bulletin of Zoology 45(5): 88-91. 
LeBlanc H.N., Logan J.G. 2010. Exploiting insect olfaction in forensic entomology. In: J. AmENDT, M.L Goff., C.P. Campobasso, M. Grassberger (Eds.). Current Concepts in Forensic Entomology. Springer Science + Business Media B.V., Dordrecht - Heidelberg - London - New York, 205-221.

Lee H.L., Krishnasamy M., Abdullah A.G., JefFery J. 2004. Review of forensically important entomological specimens in the period of 1972-2002. Tropical Biomedicine 21(2): 69-75.

LEE H.L., MARZUKi T.M. 1993. Preliminary observation of the occurrence of arthropods on carrion and its application to forensic entomology in Malaysia. Tropical Biomedicine 10(1): 5-8.

Ma, Q., Fonseca A., Liu W., Fields A.T., Pimsler M. L., Sindola A. F., Tarone A.M., CripPen T.L., TOMBERLIN J.K., Wood T.K. 2012. Proteus mirabilis interkingdom swarming signals attract blow flies. ISME Journal 6(7): 1356-1366.

MACGREGOR D.M. 1999a. Decomposition of pig carrion in southeast Queensland, Australia, during summer. Paper presented at the $51^{\text {st }}$ American Academy of Forensic Science Annual Meeting. Orlando, Florida.

MACGREGOR D.M. 1999b. Decomposition of pig carrion in southeast Queensland, Australia, during winter. Paper presented at the $51^{\text {st }}$ American Academy of Forensic Science Annual Meeting. Orlando, Florida.

Mahat N.A., Zafarina Z., JAYAPRAKASh P.T. 2009. Influence of rain and malathion on the oviposition and development of blowflies (Diptera: Calliphoridae) infesting rabbit carcasses in Kelantan, Malaysia. Forensic Science International 192(1): 19-28.

NAZNi W.A., LeE H.L., Chew W.K., AzAhari A.H., Disney R.H.L. 2011. Implications of maggot infestation in industry - First report of industrial forensic entomology. In: $47^{\text {th }}$ MSPTM Annual Conference organized by the Malaysian Society of Parasitology and Tropical Medicine. Kuala Lumpur, 3-4 March 2011. Bukit Jalil, Malaysian Society of Parasitology and Tropical Medicine, 48 .

Omar B., JefFery J., Oothuman P., Sulaiman S. 1988. A new record of Spalangia endius Walker (Hymenoptera: Pteromalidae) and a new host record of Exoristobia philippinensis ASHMEAD (Hymenoptera: Encyrtidae) for Peninsular Malaysia. Journal of Medical and Health Laboratory Technology of Malaysia 12: 10-12.

OMAR B., JefFery J., Sulaiman S. 1991. Spalangia Bouĉeki (Hymenoptera: Pteromalidae) parasitizing puparia of Musca domestica L. in Malaysia. Japanese Journal of Sanitary Zoology 42(3): 215-217.

Omar B., Marwi M.A., OоThuman P. 1992. Arthropod ecological succession as forensic indicators. Pascasidang Kolokium Perubatan 3: 40-44.

Omar B., Mohamed A.M., Sulaiman S., Oothuman P. 1994. Dipteran succession in monkey carrion at a rubber tree plantation in Malaysia. Tropical Biomedicine 11: 77-82.

Omar B., Zuha R.M., Daniel G.C.L., Abdullah W.O., JefFery J. 2008. A bionomic study of hymenopterans parasitoids at the Taman Beringin Landfill in kepong and a poultry farm in Sungai Pelek, Selangor, Malaysia. Jurnal Sains Kesihatan Malaysia 6: 15-21.

PAYNe J.A. 1965. A summer carrion study of the baby Sus scrofa LinnaEus. Ecology 46(5): 592-602. 
PoHJoismäKi J.L.O., KARHUNEN P.J., GoEBELER S., SAUKKo P., SÄÄKSJÄr V.I. 2010. Indoors forensic entomology: Colonization of human remains in closed environments by specific species of sarcosaprophagous flies. Forensic Science International 199(1): 38-42.

RichARD, E.N., GofF M.L. 1997. Arthropod successions on exposed carrion in three contrasting habitats on Hawaii Island, Hawaii. Journal of Medical Entomology 34(3): 328-339.

Rumiza A.R., Khairul O., Zuha R.M., HeO C.C. 2010. An observation on the decomposition process of gasoline-ingested monkey carcasses in a secondary forest in Malaysia. Tropical Biomedicine 27(3): 373-383.

Silahuddin S.A., Latif B., KuRahashi H., Heo C.C. 2015. The importance of habitat in the ecology of decomposition on rabbit carcasses in Malaysia: implications in forensic entomology. Journal of Medical Entomology 52(1): 9-23.

SPERLING F.A.H., ANDERSON G.S., HICKEY D.A. 1994. A DNA-based approach to the identification of insect species used for post-mortem interval estimation. Journal of Forensic Science 39(2): $418-427$.

SRINIVASAN R., Amalraj D.D. 2003. Efficacy of insect parasitoid Dirhinus himalayanus (Hymenoptera: Chalcididae) \& insect growth regulator, triflumuron against house fly, Musca domestica (Diptera: Muscidae). Indian Journal of Medical Research 118: 158-166.

Sukhapanth N., Upatham E.S., Ketavan C. 1988. Effects of feed and media on egg production, growth and survivorship of flies (Diptera: Calliphoridae, Muscidae and Sarcophagidae). Journal of the Science Society of Thailand 14(1): 41-50.

Sukontason K., Bunchu N., Chaiwong T., Moophayak K., Sukontason K.L. 2010. Forensically important flesh fly species in Thailand: morphology and development rate. Parasitology Research 106(5): 1055-1064.

Sukontason K., Sukontason K.L., Pianguai S., Chaiwong T., Boonchu N., Kurahashi H., VOGTSBeRger R.C. 2003. Larval ultrastructure of Parasarcophaga dux (THOMSON) (Diptera: Sarcophagidae). Micron 34(8): 359-364.

Sulaiman S., OMAR B., OMAR S., JefFery J. 1993. Seasonal population patterns and parasitizing activities of microhymenopteran parasitoids (Hymenoptera: Pteromalidae, Chalcidoidea) on filth flies (Diptera: Muscidae, Calliphoridae) in a poultry farm in Malaysia. Tropical Biomedicine 10: 187-190.

Sulaiman S., Omar B., Omar S., JefFery J., Ismail G., Busparani V. 1990. Survey of microhymenoptera (Hymenoptera: Chalcidodea) parasitizing filth flies (Diptera: Muscidae, Calliphoridae) breeding in refuse and poultry farms in Peninsular Malaysia. Journal of Medical Entomology 27(5): 851-855.

Sulaiman S., OMAR B., OMAR, S., JeFFery J., Ismail G., BuSPARANi V. 1991. Seasonal population patterns of Spalangia endius WALKER (Hymenoptera: Chalcidoidea) at a refuse dumping ground in Malaysia. Journal of Medical Entomology 28(6): 757-759.

Syamsa R., Ahmad F., Zuha R., Khairul A., Marwi M., Shahrom A., Omar B. 2012. An occurrence of Synthesiomyia nudiseta (WulP) (Diptera: Muscidae) from a human corpse in a high-rise building in Malaysia: a case report. Tropical Biomedicine 29(1): 107-112.

SzPILA K. 2010. Key for the identification of third instars of European blowflies (Diptera: Calliphoridae) of forensic Importance. In: J. Amendt, M.L Goff., C.P. CAmpobasso, M. 
Grassberger (Eds.). Current Concepts in Forensic Entomology. Springer Science + Business Media B.V., Dordrecht - Heidelberg - London - New York, 43-56.

Tamura K., Dudley J., Nei M., Kumar S. 2007. MEGA4: Molecular Evolutionary Genetics Analysis (MEGA) software version 4.0. Molecular Biology and Evolution 24(8): 1596-1599.

Tan S.H., Rizman-Idid M., Mohd-Aris E., Kurahashi H., Mohamed Z. 2010. DNA-based characteristic and classification of forensically important flesh flies (Diptera: Sarcophagidae) in Malaysia. Forensic Science International 199(1): 43-49.

TARONE A.M., Foran D.R. 2006. Components of developmental plasticity in a Michigan population of Lucilia sericata (Diptera: Calliphoridae). Journal of Medical Entomology 43(5): 1023-1033.

Thevan K., Abu Hassan A., Che Salmah M.R., Bhupinder S. 2013. Larval growth of Liosarcophaga dux THOMPSON (Diptera: Sarcophagidae) under uncontrolled indoor temperatures in Malaysia. Southeast Asian Journal of Tropical Medicine and Public Health 44(2): 182-187.

Triplehorn C.A., Johnson N.F. 2005. Borror and DeLong's Introduction to the Study of Insects. Thomson Brooks/Cole, Belmont, CA.

VANLAERHOVEN S.L., ANDERSON G.S. 1999. Insect succession on buried carrion in two biogeoclimatic zones of British Columbia. Journal of Forensic Science 44(1): 31-41.

VINSON S.B. 1976. Host selection by insect parasitoids. Annual Review of Entomology 21(1): $109-133$.

Voss S.C., SPAFFORD H., DADOUR I.R. 2009. Hymenopterans parasitoids of forensic importance: Host associations, seasonality, and prevalence of parasitoids of carrion flies in Western Australia. Journal of Medical Entomology 46(5): 1210-1219.

VOSS S.C., SPAFFORD H., DADOUR I.R. 2010. Temperatures-dependent development of the parasitoid Tachinaephagus zealandicus on five forensically important carrion fly species. Medical and Veterinary Entomology 24(2): 189-198.

WALl R., FisheR P. 2001. Visual and olfactory cue interaction in resource-location by the blowfly, Lucilia sericata. Physiological Entomology 26(3): 212-218.

Received: 10 January 2017

Accepted: 21 March 2017 